\title{
INOVASI PELAYANAN TRANSPORTASI PUBLIK BERBASIS TEKNOLOGI INFORMASI
}

\author{
Mar Atun Nasikhah \\ Universitas Islam Malang \\ email: nasikhah09@gmail.com
}

\begin{abstract}
ABSTRAK
Tuntutan masyarakat terhadap peningkatan pelayanan publik yang baik dan memuaskan menjadi salah satu kebutuhan yang harus dipenuhi oleh pemerintah. Penelitian ini bertujuan untuk mengetahui inovasi pelayanan publik apa saja yang sudah diterapkan pada Stasiun Malang untuk menunjang semakin majunya perkembangan zaman yang identik dengan pemanfaatan teknologi informasi sebagai salah satu produk pelayanan publik. Masalah yang diteliti dalam penelitian ini adalah bagaimana peran pemerintah terhadap inovasi pelayanan publik berbasis teknologi informasi di Stasiun Malang, selain itu apa saja yang menjadi faktor pendukung dan faktor penghambat dalam inovasi pelayanan publik berbasis teknologi informasi di Stasiun Malang, serta bagaimana tanggapan masyarakat mengenai inovasi pelayanan publik berbasis teknologi informasi di Stasiun Malang. Penelitian ini menggunakan metode deskriptif kualitatif, karena diharapkan penelitian ini akan mendapatkan ketepatan bagaimana penerapan inovasi pelayanan transportasi publik berbasis teknologi informasi di Stasiun Malang, sehingga diperlukan observasi, wawancara maupun dokumentasi sebagai teknik pengumpulan data. Berdasarkan hasil penelitian dapat disimpulkan bahwa inovasi pelayanan publik yang dihadirkan pada stasiun malang seperti: B2B (Business to Business) atau pembelian melalui Channel Eksternal, Reservasi Tiket Kereta Api H-90, CIC (Check In Center), Customer Care, Manajemen Komplain, dan Toilet Ramah Lingkungan, merupakan sebuah inovasi yang sesuai dengan kebutuhan masyarakat. Inovasi-inovasi tersebut akan memudahkan dan mempercepat masyarakat dalam melakukan proses pelayanan sehingga pelayanan menjadi lebih efektif dan efisien.
\end{abstract}

Kata Kunci: pelayanan publik, inovasi, teknologi informasi

\section{PENDAHULUAN}

\section{Latar Belakang}

Kebijakan merupakan rangkaian konsep dan asas yang menjadi pedoman dan dasar Semakin majunya perkembangan zaman yang syarat dengan pemanfaatan teknologi informasi seharusnya dapat menjadi solusi dalam masalah pelayanan publik yang ada. Teknologi informasi dapat dimanfaatkan untuk menigkatkan pelayanan menjadi lebih cepat dan transparan sehingga pelayanan publik menjadi lebih efektif dan efisien. Pelayanan publik berbasis teknologi informasi perlu diterapkan untuk mengurangi resiko terjadinya diskriminasi dalam memberikan pelayanan, ketidakpastian mengenai waktu ataupun biaya pelayanan dan tentunya mengurangi pungutan liar yang sering terjadi. 
PT. Kereta Api Indonesia (Persero) merupakan Badan Usaha Milik Negara (BUMN) yang mengelola perkeretaapian di Indonesia. Kita ketahui sebelumnya bahwa pelayanan perkeretaapian di Indonesia khususnya kereta api kelas ekonomi rawan dengan permasalahan di antaranya tempat duduk berdesakan, pencopetan, fasilitas toilet kurang, serta keterlambatan kedatangan maupun keberangkatan kereta. Namun ternyata akhir tahun 2012 kemarin PT. KAI berhasil memperoleh penghargaan BUMN award kategori inovasi pelayanan publik. Hal ini menjadi titik terang perkembangan kualitas pelayanan perkeretaapian di Indonesia, apakah sudah semakin mendekati kriteria transportasi berkelanjutan yang sudah manfaatkan teknologi informasi atau belum. Penulis mengkhususkan penelitian pada PT. Kereta Api Indonesia (Persero) yang berada di Kota Malang dikarenakan kota Malang merupakan kota besar yang juga berpotensi menghadapi permasalahan transportasi dengan peningkatan kendaraan bermotornya. Selain melihat kualitas pelayanannya, peneliti juga ingin melihat peran pemerintah dalam meningkatkan kualitas pelayanan pada PT. Kereta Api Indonesia (Persero) serta faktor pendukung dan penghambat yang dihadapi dengan harapan dapat menghimbau pengurangan penggunaan kendaraan pribadi yang dapat berdampak serius terhadap kerusakan lingkungan, selain itu dapat mengetahui bahwa perkembangan perkeretaapian dapat mendukung terwujudnya transportasi berkelanjutan.

PT. Kereta Api Indonesia (Persero) telah menyediakan fasilitas untuk melayani pengguna jasa dalam melakukan transaksi pembelian tiket melalui sejumlah tempat. Pertama, penjualan di loket PT. Kereta Api Indonesia (Persero). Penjualan melalui loket di stasiun dilayani mulai 90 hari sampai 1 jam sebelum keberangkatan. Kedua, penjualan melalui agen. Penjualan lewat agen dilayani mulai dari 90 hari sampai 1 jam sebelum keberangkatan kereta api. Ketiga, pembayaran melalui internet banking dan ATM Bank (Mandiri, BII, BRI). Penjualan atau pemesanan melalui ATM dilakukan melalui call center yang sudah ada kerjasama dengan PT. Kereta Api Indonesia (Persero). Keempat, penjualan melalui loket PT. Pos Indonesia. Penjualan tiket melalui PT. Pos Indonesia dilayani mulai 90 hari sampai 1 hari sebelum keberangkatan kereta api. PT. Kereta Api Indonesia (Persero) memperluas jaringan pelayanan E-Ticketing ini sebagai wujud kepedulian terhadap tuntutan akan peningkatan kualitas pelayanan dan kemudahan akses. Salah satunya adalah kemudahan dalam memperoleh tiket kereta api bagi para pengguna jasa angkutan kereta api pada kelas bisnis dan eksekutif.

Sejumlah inovasi tersebut tentunya diharapkan mampu memberikan kontribusi bagi peningkatan okupansi (banyaknya) penumpang kereta api.

Berdasarkan uraian latar belakang di atas maka peneliti tertarik untuk mengambil judul penelitian "Inovasi Pelayanan Transportasi Publik Berbasis Teknologi Informasi (Studi Pada Stasiun Kereta Api Kota Malang)”.

\section{Rumusan Masalah}

Berdasarkan uraian latar belakang diatas maka peneliti dapat menarik beberapa rumusan masalah sebagai berikut:

a. Bagaimana peran pemerintah dalam inovasi pelayanan transportasi publik berbasis teknologi informasi pada Stasiun Kereta Api Kota Malang?

b. Apa saja faktor pendukung dan penghambat pada inovasi pelayanan transportasi publik berbasis teknologi informasi pada Stasiun Kereta Api Kota Malang?

c. Bagaimana tanggapan masyarakat sebagai pengguna jasa transportasi Kereta Api terhadap inovasi pelayanan transportasi publik berbasis teknologi informasi pada Stasiun Kereta Api Kota Malang? 


\section{Tujuan Penelitian}

Tujuan dari penelitian ini antara lain:

a. Untuk mengetahui peran pemerintah dalam inovasi pelayanan transportasi publik berbasis teknologi informasi pada Stasiun Kereta Api Kota Malang.

b. Untuk mengetahui faktor pendukung dan penghambat pada inovasi pelayanan transportasi publik berbasis teknologi informasi pada Stasiun Kereta Api Kota Malang.

c. Untuk mengetahui tanggapan masyarakat sebagai pengguna jasa transportasi Kereta Api terhadap inovasi pelayanan transportasi publik berbasis teknologi informasi pada Stasiun Kereta Api Kota Malang.

\section{Manfaat Penelitian}

Adapun manfaat dari penelitian ini yakni:

a. Manfaat Praktis

> Bagi pemerintah kota Malang, diharapkan dengan adanya penelitian ini dapat memberikan gambaran tentang inovasi pelayanan transportasi publik dalam hal ini adalah Kereta Api Indonesia dalam memanfaatkan teknologi informasi untuk meningkatkan kualitas produk pelayanan publik.

$>$ Bagi PT Kereta Api Indonesia (Persero) Malang, diharapkan dengan adanya penelitian ini dapat dijadikan sebagai acuan atau semangat untuk terus berinovasi dalam meningkatkan kualitas pelayananya dengan menggunakan teknologi informasi sebagai salah satu jawaban dari kemajuan jaman.

> Bagi masyarakat pengguna jasa transportasi Kereta Api, diharapkan dengan adanya penelitian ini dapat memberikan pengetahuan yang mendalam tentang kemajuan pelayanan publik pada jasa transportasi kereta api, sehingga masyarakat bisa memanfaatkan semua fasilitas yang ada dengan bijak.

b. Manfaat Akademis

> Bagi peneliti lain, diharapkan dengan adanya penelitian ini dapat dijadikan sebagai referensi untuk penelitian-penelitian selanjutnya mengenai Inovasi pelayanan transportasi publik.

> Bagi pembaca, diharapkan dengan adanya penelitian ini dapat memberikan gambaran serta menambah wawasan pengetahuan mengenai inovasi pelayanan publik pada transportasi publik.

\section{TINJAUAN PUSTAKA}

\section{Jenis Penelitian}

Penelitian kualitatif dengan susunan metode deskriptif. Jenis penelitian ini sengaja dipilih karena dalam jenis ini tidak hanya berambisi mengumpulkan data dari segi kualitas tetapi juga ingin memperoleh pemahaman yang lebih mendalam dibalik fenomena yang berhasil direkam. Berupaya untuk memberikan gambaran secara luas atau uraian atas suatu keadaan atau fenomena social pendidikan secara jelas tanpa ada perlakuan terhadap obyek yang diteliti dan yang terjadi.

\section{Fokus Penelitian}

Adapun fokus dalam penelitian ini adalah:

a. Peran pemerintah dalam rangka inovasi pelayanan transportasi publik berbasis teknologi informasi pada Stasiun Kereta Api Kota Malang, dengan sub fokus:

$>$ Peran pemerintah dalam rangka inovasi pelayanan transportasi publik.

$>$ Inovasi pelayanan transportasi publik berbasis teknologi informasi. 
b. Faktor pendukung dan penghambat inovasi pelayanan transportasi publik berbasis teknologi informasi pada Stasiun Kereta Api Kota Malang, dengan sub fokus:

$>$ Faktor pendukung inovasi pelayanan transportasi publik berbasis teknologi informasi.

$>$ Faktor penghambat inovasi pelayanan transportasi publik berbasis teknologi informasi.

c. Tanggapan masyarakat sebagai pengguna jasa transportasi Kereta Api terhadap inovasi pelayanan transportasi publik berbasis teknologi informasi pada Stasiun Kereta Api Kota Malang, dengan sub fokus:

$>$ Tanggapan masyarakat sebagai pengguna jasa transportasi Kereta Api terhadap inovasi pelayanan transportasi publik berbasis teknologi informasi.

$>$ Tanggapan penyedia jasa terhadap inovasi pelayanan transportasi publik berbasis teknologi informasi.

\section{Lokasi Dan Situs Penelitian}

Penetapan lokasi penelitian merupakan tahap yang sangat penting dalam penelitian kualitatif, karena dengan ditetapkanya lokasi penelitian berarti objek dan tujuan sudah ditetapkan sehingga mempermudah peneliti dalam melakukan penelitian. Oleh sebab itu peneliti menentukan lokasi penelitian di Stasiun Kereta Api Kota Malang.

Situs penelitian adalah tempat dimana peneliti dapat menangkap keadaan yang sebenarnya dari obyek yang diteliti untuk memperoleh data atau informasi yang diperlukan. Sehingga peneliti menentukan situs penelitian di Bagian Pelayanan pada Stasiun Kereta Api Kota Malang.

\section{Jenis Dan Sumber Data}

Jenis dan sumber data yang digunakan dalam penelitian ini yakni:

a. Jenis Data

$>$ Data primer

Adalah hasil wawancara dengan responden berupa kata-kata, tindakan, keterangan serta informasi yang dikumpulkan serta mengamati dan mencatat kejadian yag terjadi di lapangan. Pada umumnya sumber data primer berupa person.

$>$ Data sekunder

Adalah dokumen-dokumen seperti studi pustaka digunakan untuk memperoleh data dan informasi yang berhubungan menunjang dengan permasalahan penelitian. Data sekunder yang digunakan dalam penelitian ini berupa paper (dokumen).

b. Sumber Data

Sumber data adalah orang atau subyek yang dapat memberikan informasi yang dibutuhkan pada suatu penelitian. Sumber data ini merupakan unsur pokok dan cukup menentukan keberhasilan penelitian. Adapun yang menjadi sumber data primer pada penelitian ini adalah:

$>$ Kepala Bagian Pelayanan Pada Stasiun Kereta Api Kota Malang

$>$ Pengguna Jasa Transportasi Kereta Api

Sedangkan pada jenis data sekunder peneliti mengambil sumber data yang peneliti gunakan adalah :

$>$ Stasiun Kereta Api Kota Malang 


\section{Teknik Pengambilan Sampling}

Dalam penelitian kualitatif ini peneliti menggunakan teknik purposive sampling. Menurut Sugiyono (2016:218) mengemukakan bahwa Purposive sampling adalah teknik pengambilan sampel sumber data dengan pertimbangan tertentu. Pertimbagan tertentu ini, misalnya orang tersebut yag diaggap paling tahu tentang apa yag kita harapkan, atau mungkin dia sebagai penguasa sehingga akan memudahkan peneliti menjelajahi obyek/situasi sosial yang diteliti.

\section{Teknik Pengumpulan Data}

Adapun teknik pengumpulan data yang akan dilakukan oleh peneliti ada tiga macam teknik, yakni:

a. Observasi

Observasi atau pengamatan merupakan aktifitas pencatatan fenomena yang dilakukan secara sistematis. Pengamatan dapat dilakukan secara partisipatif (terlibat) ataupun non partisipatif.

b. Wawancara / Interview

Wawancara adalah teknik pengumpulan data dengan cara mengadakan Tanya jawab secara langsung dengan pihak yang bersangkutan dengan permasalahan yang diangkat dalam penelitian guna mendapatkan data dan keterangan yang berlandaskan kepada tujuan penelitian. Jenis wawancara yang dilakukan adalah wawancara semistruktur, dimana dalam pelaksanaanya lebih bebas bila dibandingkan dengan wawancara terstruktur.

c. Dokumentasi

Dokumentasi yaitu teknik mencari data mengenai hal-hal yang berupa catatan, transkip, buku, surat kabar, majalah, prasasti notulen, rapat, lengger, agenda, dan sebagainya. Dokumentasi dalam pengumpulan data dimaksutkan sebagai cara mengumpulkan data dengan mempelajari dan mencatat bagian-bagian yang dianggap penting yang terdapat baik dilokasi penelitian maupun diinstansi yang ada hubunganya dengan lokasi penelitian.

\section{Keabsahan Data}

Penelitian ini menggunakan tiga macam trianggulasi, yang pertama, trianggulasi sumber data yang berupa informasi dari tempat, peristiwa dan dokumen serta arsip yang memuat catatan berkaitan dengan data yang dimaksud. Kedua, trianggulasi teknik atau metode pengumpulan data yang berasal dari wawancara, observasi, dan dokumen. Ketiga, trianggulasi waktu pengumpulan data merupakan kapan dilaksanakannya trianggulasi atau metode pengumpulan data. Keabsahan data dalam penelitian ini menggunakan trianggulasi, Sugiyono (2006:273-274), menjelaskan ada tiga macam trianggulasi. Ketiga trianggulasi tersebut yaitu triangulasi sumber, pengumpulan data, dan waktu.

\section{Teknik Analisis Data}

Teknik analisis data kualitatif pada penelitian ini menggunakan model fenomenologi Spradley secara keseluruhan proses penelitian terdiri atas: pengamatan deskriptif, analisis domein, pengamatan terfokus, analisis taksonomi, pengamatan terpilih, analisis komponensial, dan diakhiri dengan analisis tema (Moleong, 2010:302). Proses tersebut dapat disederhanakan dalam empat tahap sebagai berikut: 
a. Analisis Domain

Analisis domain pada umumnya dilakukan untuk memperoleh gambaran yang umum dan menyeluruh tentang situasi social yang diteliti atau objek penelitian. Data yang diperoleh dari observasi, wawancara, dan studi dokumen. Hasilnya berupa gambaran umum tentang objek yang diteliti, yang sebelumnya belum pernah diketahui.

b. Analisis Taksonomi

Analisis taksonomi adalah analisis terhadap keseluruhan data yang terkumpul berdasarkan domain yang telah ditetapkan. Dengan demikian domain yang telah ditetapkan menjadi cover term oleh peneliti dapat diurai lebih terperinci dan mendalam melalui analisis taksonomi ini. Setelah cover term atau domain terpilih maka melalui pencarian data laindan analisis taksonomi akan ditemukan fokus dari domain yang dipilih dan lebih mengerucutkan penelitian yang selanjutnya akan dilanjutkan dengan analisis komponensial sebagai tahap akhir sebelum di temukan conclusion atau kesimpulan.

c. Analisis Komponensial

Pada analisis komponensial yang dicari untuk diorganisasikan dalam domain bukanlah serupa dalam domain, tetapi justru memiliki perbedaan atau yang kontras. Data yang dicari melalui observasi, wawancara dan dokumentasi yang terseleksi. Dengan teknik pengumpulan data yang bersifat triangulasi tersebut sejumlah data spesifik dan berbeda pada setiap elemen akan dapat ditemukan.

d. Analisis Tema Budaya

Analisis tema budaya (discovering cultural themes), sesungguhnya merupakan upaya mencari "benang merah" yang mengintegrasikan lintas domain yang ada. Dengan ditemukan benang merah dari hasil analisis domain, taksonomi dan komponensial tersebut, maka selanjutnya akan dapat tersusun suatu "konstruksi bangunan" situasi sosial/objek penelitian yang sebelumnya masih belum terfokus, dan setelah dilakukan penelitian, maka menjadi lebih terang atau terfokus dan akhirnya kesimpulan dapat dijelaskan secara deskriptif menggunakan predikat.

\section{HASIL DAN PEMBAHASAN}

\section{Peran Pemerintah Dalam Rangka Inovasi Pelayanan Transportasi Publik}

Pemerintah sebagai pemilik infrastruktur kereta api mempunyai peran yang sangat penting dalam usaha peningkatan mutu pelayanan pada kereta api. Seperti dalam hal pembangunan Double Track yang saat ini terus digencarkan mengingat semakin meningkatnya jumlah penumpang kereta api pada setiap tahunya.

Sebagai salah satu transportasi publik yang menjadi pilihan masyarakat, Stasiun Malang selalu berusaha memberikan informasi melalui beberapa cara apabila terdapat sebuah produk baru yang sifatnya inovasi. Salah satu yang dimanfaatkan oleh Stasiun Malang sebagai media sosialisasi yakni pada event car free day yang berlangsung setiap hari Minggu pagi. Dalam even ini pihak Stasiun Malang mencoba memberikan beberapa informasi mengenai kereta api seperti contoh ketika adanya sebuah inovasi yang dihadirkan pada stasiun malang. Selain itu Stasiun Malang juga menggunakan media radio sebagai salah satu cara yang digunakan untuk bersosialisasi pemberian informasi mengenai kereta api.

Demi terciptanya sebuah transportasi publik yang selalu mengedepankan pelayanan kepada masyarakat, pemerintah dalam hal ini Kementrian Perhubungan selalu memberikan monitoring langsung kepada Stasiun Malang. Monitoring ini dilakukan secara berkala setiap 6 bulan sekali dan setahun sekali. Monitoring setiap 6 
bulan sekali dilakukan pada program PSO (Public Service Obligation) dan monitoring setahun sekali dilakukan untuk pengecekan standar pelayanan pada stasiun.

\section{Inovasi Pelayanan Transportasi Publik Berbasis Teknologi Informasi Pada Stasiun Kereta Api Kota Malang}

\section{a. B2B (Business to Business) Atau Pembelian Melalui Channel External}

Program $B 2 B$ ini merupakan hasil kerjasama antara PT. KAI dengan perusahaan lain yang memliki sistem pembayaran tersendiri. Channel eksternal yang dimiliki PT. KAI diantaranya Indomaret, Alfamart, Kantor Pos, Gerai Fastpay, PPOB BRI - Delaprasta, Fin Channel, Pegadaian, Cooppay dan lain-lain yang tersebar di seluruh Indonesia.

Selain dapat menghemat waktu dan biaya karena tidak perlu datang dan mengantri di stasiun, setiap pembelian tiket melalui channel eksternal juga akan mendapatkan diskon sebesar Rp. 7.500.00 per tiketnya. Sedangkan biaya pemesanan tiket pada channel eksternal sebesar Rp. 7.500.00 per satu kode booking yang dapat digunakan untuk maksimal empat tiket sekaligus.

b. Reservasi Tiket Kereta Api H-90

Reservasi tiket kereta api H-90 adalah inovasi penjualan tiket kereta api yang diterapkan dengan melayani pembelian tiket kereta api mulai $\mathrm{H}-90$ atau 90 hari sebelum keberangkatan. Reservasi tiket ini dapat dilakukan pada seluruh channel penjualan tiket kereta api yang sudah terkoneksi degan RTS (Rail Ricket System). Hal ini juga memberikan nilai tambah bagi konsumen dalam kemudahan mendapatkan tiket. Melalui inovasi ini, calon penumpang diajarkan untuk terbiasa membeli tiket kereta api jauh hari sebelum keberangkatan agar para calon penumpang tidak berdesak-desakan dalam mendapatkan tiket kereta api.

c. CIC (Check In Center)

Berdasarkan hasil penelitian, layanan $C I C$ dapat mempercepat penumpang kereta api dalam mencetak tiketnya. Dibandingkan dengan mencetak tiket di loket stasiun yang membutuhkan waktu lebih lama karena penumpang yang akan mencetak tiketnya harus antri dengan penumpang lainya yang ingin membeli tiket, membatalkan tiket dan pengembalian uang tiket yang telah dibatalkan (refund). Terdapat perbedaan antara mencetak tiket di loket stasiun dengan menggunakan layanan CIC. Apabila mencetak pada loket stasiun ada petugas loket yang akan membantu mencetakkan tiket, akan tetapi jika menggunakan mesin CIC penumpang harus mencetak tiketnya sendiri. Secara tidak langsung dengan adanya layanan CIC ini menjadikan penumpang kereta api lebih mandiri dan mengurangi jumlah antrian di loket stasiun.

d. Customer Care

Layanan konsumen atau customer care PT. KAI terdapat beberapa saluran. Tidak hanya menggunakan sambungan telepon, akan tetapi juga menggunakan media sosial seperti facebook, twitter maupun e-mail (surat elektronik). Penggunaan berbagai saluran komunikasi tersebut ditujukan untuk memudahkan komunikasi antara konsumen (dalam hal ini penumpang) dengan pihak PT. Kereta Api Indonesia (persero) selaku penyedia jasa transportasi. Salah satu dari manfaatnya yaitu mendapatkan kemudahan dalam melakukan reservasi tiket kereta api secara online. Selain itu juga, menggunakan media sosial akan menciptakan arus komunikasi terbaru yang lebih mudah diterima konsumen, contohnya seperti pemberian informasi lowongan kerja. 


\section{e. Manajemen Komplain}

Hasil pengamatan menunjukkan bahwa keluhan penumpang yang berada pada sarana dan prasarana, keterlambatan kereta, ticketing dan failitas stasiun. Prosedur penanganan keluhan pelanggan kereta api lokal dilakukan secara langsung yaitu dengan cara mendengarkan keluhan penumpang, mencatat semua yang dikeluhkan penumpang kemudian penyelesaian masalah dilakukan secara langsung maupun tertulis yaitu dengan menginventariskan data melalui kotak saran, website dan media cetak atau elektronik kemudian dijawab pada media yang sama seperti yang digunakan. Keluhan yang masuk di stasiun Malang akan segera ditindak lanjuti, kemudian akan dievaluasi agar kedepanya pelayanan yang diberikan sesuai dengan harapan penumpang.

f. Toilet Ramah Lingkungan

Toilet ramah lingkungan ini mengacu pada prinsip bersih, tidak menimbulkan bau dan higienis. Limbah diproses dengan mikrobakteri sebelum dibuang ke track (jalur) kereta api.

Toilet ramah lingkungan kereta api secara sederhana memadukan sistem pembilasan (flushing) dan sanitasi. Sistem pembilasan menggunakan udara bertekanan untuk mengalirkan limbah toilet ke tangki penampungan. Berikutnya, dengan sistem sanitasi di dalam tangki penampungan terjadi proses penguraian atau dekomposisi limbah. Di dalam tangki penampungan disediakan jalur pengisian mikrobakteri yang prinsipnya menguraikan limbah padat menjadi gas dan cairan.

\section{Faktor Pendukung Dan Penghambat Inovasi Pelayanan Transportasi Publik} Berbasis Teknologi Informasi Pada Stasiun Kereta Api Kota Malang

a. Faktor Pendukung Inovasi Pelayanan Transportasi Publik Berbasis Teknologi Informasi

Berdasarkan dari hasil penelitian ada dua faktor yang mempengaruhi keberhasilan suatu inovasi di Stasiun Malang. Yakni faktor internal dan faktor eksternal. Faktor internal ini sendiri berhubungan dengan bagaimana pihak Stasiun Malang mampu menghadirkan sebuah produk-produk baru baik yang sifatnya inovasi atau memperbaiki. Sehingga pihak Stasiun Malang harus mengetahui apa yang saat ini sedang dibutuhkan oleh masyarakat.

Faktor pendukung yang kedua yakni faktor eksternal. Faktor eksternal disini berhubungan dengan masyarakat sebagai pengguna jasa layanan angkutan kereta api. Sebagai pengguna angkutan kereta api masyarakat tentu mempunyai andil yang besar dalam suksesnya sebuah inovasi pada Stasiun Malang. Tuntutan terhadap peningkatan pelayanan publik yang baik dan memuaskan kepada masyarakat menjadi suatu kebutuhan yang harus dipenuhi oleh para penyedia jasa. Namun keberhasilan semua ini tidak seamata-mata bergantung pada para penyedia jasa saja. Masyarakat juga harus turut serta ikut dalam menyukseskan inovasi yang ada.

b. Faktor Penghambat Inovasi Pelayanan Transportasi Publik Berbasis Teknologi Informasi

Berdasarkan dari hasil penelitian di stasiun Malang ini sendiri faktor penghambatnya mungkin relatif tidak ada karena kita tahu masyarakat di perkotaan sudah semakin pintar dalam penggunaan teknologi. Sehingga hal itu bukan menjadi suatu ketakutan besar dari pihak Stasiun Malang apabila akan memunculkan sebuah inovasi yang berbau teknologi. Namun yang menjadi kendala salah satunya adalah kejadian lumpur lapindo di Porong. Karena hal tersebut bisa mengakibatkan rel pada sekitar kejadian lumpur lapindo amblas ketika terjadi banjir. Sehingga apabila hal itu terjadi 
maka jalur perlintasan kereta api dari Malang menuju Surabaya atau lewat Surabaya tidak bisa digunakan atau ditutup untuk sementara. Meskipun pemerintah sudah berencana untuk membangun jalur alternatif melingkar di Porong namun kenyataanya sampai saat ini program tersebut masih sebatas rencana saja belum ada kejelasan.

\section{Tanggapan Masyarakat Sebagai Pengguna Jasa Transportasi Kereta Api Terhadap Inovasi Pelayanan Transportasi Publik Berbasis Teknologi Informasi Pada Stasiun Kereta Api Kota Malang.}

\section{a. Tanggapan Masyarakat Sebagai Pengguna Jasa Transportasi Kereta Api}

Berdasarkan sepuluh dimensi yang digunakan untuk mengukur kualitas pelayanan, kemudian Zeithaml et.al. (1990) dalam Hardiyansyah (2011:42) menyederhanakan menjadi lima dimensi, yaitu dimensi SERVQUAL (kualitas pelayanan) sebagai berikut:

$>$ Tangibles

Meliputi fasilitas fisik, perlengkapan, pegawai, dan sarana komunikasi; menurut penelitian Stasiun Malang merupakan stasiun kelas besar yang didalamnya sudah terdapat fasilitas yang memadahi, mulai dari ruang tunggu, loket, toilet, AC, tempat makan, cafeteria, took-toko yang menjual berbagai kebutuhan selama perjalanan. Tentunya beberapa fasilitas tersebut akan lebih memanjakan masyarakat sebagai penumpang kereta api.

$>$ Realibility

Yaitu kemampuan untuk memberikan pelayanan yang dijanjikan tepat waktu dan memuaskan; dari hasil penelitian pemberian pelayanan dari Stasiun Malang selalu diusahakan seoptimal mungkin sesuai dengan tujuanya yakni peningkatan konsumen, salah satu cara untuk meningkatkan konsumen yakni dengan memberikan pelayanan yang memuaskan pada setiap proses pelayanan.

$>$ Responsiveness

Kemampuan para staf untuk membantu para pelanggan dan memberikan pelayanan yang tanggap. Stasiun Malang sebagai stasiun yang mempunyai volume penumpang yang besar setiap harinya tentu harus siap dan tanggap dalam memberikan pelayananan. Seluruh staf atau pegawai pada stasiun Malang selalu dikondisikan untuk memahami semua bentuk proses pelayanan, sehingga siapa saja pegawai yang ada di stasiun Malang harus mampu ketika dihadapkan langsung dengan masyarakat ketika dimintai tolong dalam hal proses pelayanan.

$>$ Assurance

Mencakup kemampuan, kesopanan, bebas dari bahaya resiko atau keraguan. Stasiun kereta api kota Malang berupaya untuk memberikan situasi pelayanan yang aman dan nyaman, sehingga pada Stasiun malang terdapat security dan polsuska yang membantu menjaga keamanan dan ketertiban penumpang baik dalam stasiun maupun dalam perjalanan kereta api.

$>$ Emphaty

Yaitu mencakup kemudahan dalam melakukan hubungan komunikasi yang baik dan memahami kebutuhan para pelanggan. Stasiun Malang selalu berusaha mengkondisikan untuk menghadirkan berbagai inovasi yang berbentuk teknologi informasi sebagai salah satu bentuk pelayanan yang diinginkan masyarakat. Sehingga hal ini akan membuat kereta api semakin dicintai oleh masyarakat. 


\section{b. Tanggapan Penyedia Jasa Terhadap Inovasi Pelayanan Publik Berbasis Teknologi Informasi}

Dari hasil penelitian pada Stasiun Malang setiap tahunya mengalami kenaikan volume penumpang. Terhitung sejak 2015-2017 peningkatan volume penumpang mengalami kenaikan sekitar 20-30 \% setiap tahunya dan tingkat kepuasan pelanggan mencapai angka 70-80 \%. Hal ini bisa terjadi karena adanya upaya peningkatan kualitas pelayanan pada stasiun Malang. Setiap ada gagasan-gagasan baru dari pusat mengenai peningkatan produk pelayanan, Stasiun Malang selalu mengkondisikan untuk sesegera mungkin melakukan pembaruan sesuai dengan ketentuan yang berlaku. Tentu hal ini menjadi suatu pencapaian tersendiri bagi pihak Stasiun Malang karena inovasi yang dihadirkan sudah bisa diterima oleh masyarakat. Sehingga dengan adanya kualitas pelayanan yang memuaskan tentu trasnportasi kereta api akan semakin dicintai oleh masyarakat.

\section{KESIMPULAN}

Dari hasil penelitian dan pembahasan, maka peneliti dapat menarik kesimpulan sebagai berikut:

1. Inovasi-inovasi yang sudah diterapkan pada Stasiun Malang antara lain: (1) B2B (Business to Business) atau Pembelian melalui channel external, Program B2B ini merupakan hasil kerjasama antara PT KAI dengan perusahaan lain yang memiliki sistem pembayaran tersendiri. Channel eksternal yang dimiliki PT KAI diantaranya Indomaret, Alfamart, Kantor Pos, Gerai Fastpay, PPOB BRI - Delaprasta, Fin Channel, Pegadaian, Cooppay dan lain-lain yang tersebar diseluruh Indonesia, (2) Reservasi Tiket Kereta Api H-90 adalah inovasi penjualan tiket kereta api yang diterapkan dengan melayani pembelian tiket kereta api mulai $\mathrm{H}-90$ atau 90 hari sebelum keberangkatan. (3) CIC (Check In Center), Layanan CIC dapat mempercepat penumpang kereta api dalam mencetak tiketnya. Terdapat perbedaan antara mencetak tiket di loket stasiun dengan Layanan $C I C$. Apabila di loket stasiun ada petugas loket yang akan mencetakkan tiket, akan tetapi pada Layanan CIC penumpang harus mencetak tiketnya sendiri. (4) Customer Care, Layanan konsumen PT KAI terdapat beberapa saluran. Tidak hanya menggunakan sambungan telepon, akan tetapi juga menggunakan media sosial seperti facebook, twitter maupun e-mail (surat elektronik). Penggunaan berbagai saluran komunikasi tersebut ditujukan untuk memudahkan komunikasi antara konsumen (dalam hal ini penumpang) dengan pihak PT Kereta Api selaku penyedia jasa transportasi. (5) Manajemen Komplain (complaint management), Salah satu wujud dari manajemen komplain yang belakangan dipilih oleh PT. Kereta Api Indonesia adalah penyediaan saluran telepon khusus (call center) bagi pelanggan untuk berkomunikasi secara langsung dengan pihak kereta api yang bertugas, dimana pelanggan bisa memperoleh informasi dan/atau menyampaikan keluhan (komplain) secara langsung. (6) Toilet ramah lingkungan, mengacu pada prinsip bersih, tidak menimbulkan bau, dan higienis. Limbah diproses dengan mikrobakteri sebelum dibuang di track (jalur) kereta api.

2. Pemerintah dalam hal ini adalah kementrian perhubungan sebagai pemilik infrastruktur kereta api mempunyai peran yang sangat besar dalam pengembangan layanan jasa angkutan kereta api. pada proses pelayananya pemerintah bertidak sebagai regulator sedangkan PT. Kereta Api Indonesia bertindak sebagai operator yang memberikan jaminan pelayanan pada setiap penumpang.

3. Faktor pendukung inovasi pelayanan publik pada stasiun Malang terdiri dari dua faktor, yakni faktor internal dan faktor eksternal. Faktor internal ini sendiri berhubungan dengan bagaimana pihak Stasiun Malang mampu menghadirkan sebuah produk-produk baru baik yang sifatnya 
inovasi atau memperbaiki sesuai dengan apa yang dibutuhkan masyarakat. sedangkan faktor eksternalnya muncul dari masyarakat sebagai pengguna jasa kereta api harus ikut serta aktif dalam menjaga dan menyukseskan inovasi pelayanan yang ada pada stasiun.

4. Faktor penghambat dari inovasi pelayanan publik pada stasiun Malang relatif tidak ada karena kita tahu masyarakat di perkotaan sudah semakin pintar dalam penggunaan teknologi. Sehingga hal itu bukan menjadi suatu ketakutan besar dari pihak Stasiun Malang apabila akan memunculkan sebuah inovasi yang berbasis teknologi. Namun yang menjadi kendala salah satunya adalah faktor alam seperti kejadian lumpur lapindo di Porong. Karena hal tersebut bisa mengakibatkan rel pada sekitar kejadian lumpur lapindo amblas ketika curah hujan tinggi dan terjadi banjir. Sehingga apabila hal itu terjadi maka jalur perlintasan kereta api dari Malang menuju Surabaya atau lewat Surabaya tidak bisa digunakan. Tentu hal itu akan menghambat layanan pada kereta api.

5. Dari hasil analisis kepuasan pelanggan menggunakan analisis SERVQUAL yang meliputi lima dimensi yakni tangibles, realibility, responsiveness, assurance, emphaty. Menunjukkan bahwa masyarakat sebagai pengguna jasa kereta api menganggap bahwa beberapa inovasi yang dihadirkan pada Stasiun Malang sudah sesuai dengan apa yang dibutuhkan oleh masyarakat. karena semua inovasi yang dihadirkan pada stasiun Malang akan memudahkan masyarakat dan membuat pelayanan lebih efektif dan efisien.

6. Stasiun Malang sebagai penyedia jasa transportasi kereta api juga berpendapat bahwa inovasiinovasi yang dihadirkan sudah sesuai dengan keinginan dan kebutuhan msyarakat. Hal ini terbukti adanya peningkatan volume penumpang di Stasiun Malang hingga mencapai angka 20$30 \%$ setiap tahun. Selain itu angka kepuasan pelanggan mencapai 70-80 \% (data wawancara 23 April 2018)

\section{SARAN}

1. Perlu adanya penambahan loket pada tiket kereta api lokal untuk mengurangi jumlah antrian. Mengingat jumlah loket yang disediakan oleh stasiun malang tidak sepadan dengan jumlah penumpang kereta api lokal.

2. Perlu adanya penambahan loket khusus untuk lansia. Mengingat tidak semua masyarakat mampu mengkuti perkembangan teknologi seperti halnya lansia.

3. Perlu adanya penambahan fasilitas seperti tempat duduk pada ruang tunggu dan halaman parkir. Mengingat peminat kereta api semakin meningkat setiap tahun.

4. Penempatan mesin CIC (Check In Center) perlu diperluas. Tidak hanya ditempatkan pada stasiun kelas besar saja (A) namun juga perlu ditempatkan pada stasiun kelas B dan C. selain itu penempatan mesin CIC (Check In Center) pada ruang publik seperti Mall atau pusat perbelanjaan dapat dijadikan salah satu alternative solusi peningkatan pelayanan publik.

5. Perlu adanya perluasan bentuk sosialisasi. Meskipun sosialisasi mengenai inovasi pelayanan publik ini sudah dilakukan oleh pihak Stasiun Malang, namun banyak dari masyarakat yang belum mengetahui tentang adanya sosialisasi ini. Seperti sosialisasi melalui media social yang sangat digemari oleh masyarakat saat ini yakni Televisi, Youtube, Instagram atau bahkan melalui penampilan pada Video Tron yang terpasang pada bagian-bagian jalan tertentu di kota Malang.

\section{DAFTAR RUJUKAN}

\section{Sumber Buku :}

Arikunto, Suharsimi. 1998. Prosedur Penelitian: Suatu Pendekatan Praktek. Jakarta: PT Rineka Cipta.

Hamidi, Jazim. 2004. Metode Penelitian Kualitatif. Malang: UMMP Press.

Hardiansyah. 2011. Kualitas Pelayanan Publik. Yogyakarta: Gava Media.

Kusmana, Suherli. 2010. Manajemen Inovasi Pendidikan. Ciamis: Pascasarjana Unigal Press. Lupiyoadi, Rambat. 2001. Manajemen Pemasaran Jasa. Jakarta: PT. Salemba Empat.

Moenir, H.A.S . 1995. Manajemen Pelayanan Umum. Jakarta: PT. Bumi Aksara.

Moleong, J. Lexi. 2008. Metodologi Penelitian Kualitatif. Jakarta: Rosda. 
Muluk, Khairul. 2008. Knowledge Management Kunci Sukses Inovasi Pemerintahan Daerah. Jatim: Bayumedia Publising.

Muchayat. 2010. BUMN dalam bingkai pembangunan. Bandung: Alfabeta.

Satori, Djama'an dan Aan Komariyah. 2005. Metode Penelitian Kualitatif. Bandung: Alfabeta. Sedarmayanti. 2010. Manajemen Sumber Daya Manusia Reformasi Birokrasi dan. Manajemen Pegawai Negeri Sipil. Bandung: PT Refka Aditama.

Siagian, Sondang P. 2001. Manajemen Sumber Daya Manusia. Jakarta: PT Bumi Aksara.

Sinambela, Lijan Poltak. Dkk. 2011. Reformasi Pelayanan Publik. Jakarta: PT Bumi Aksara.

Spradley, J.P. 1980. The Participant Observations. New York: Reinhart \& Winston.

Sugiyono. 2006. Metode Penelitian Kuantitatif, Kualitatif, dan R\&D. Bandung: Alfabeta.

Sugiyono. 2009. Metodologi Penelitian Kualitatif. Bandung: Alfabeta.

Sugiyono. 2013. Metode Penelitian Administrasi. Bandung: Alfabeta.

Sugiyono. 2016. Metode Penelitian Kuantitatif, Kualitatif, dan R\&D. Bandung: Alfabeta.

Surjadi. 2009. Pengembangan Kinerja Pelayanan Publik. Bandung: PT Rafika Aditama.

Syafiudin, Azwar. 2013. Metode Penelitian. Yogyakarta: Pustaka Belajar.

Tjiptono, Fandy. 2001. Kualitas Jasa: Pengukuran, Keterbatasan dan Implikasi Manajerial, Jakarta: majalah Manajemen Usahawan Indonesia.

\section{Sumber Jurnal:}

Alvin Havianto. 2013. "Strategi Peningkatan Kualitas Pelayanan Publik (Studi Deskriptif tentang Strategi Dinas Cipta Karya dan Tata Ruang Kota Surabaya dalam Peningkatan Kualitas Pelayanan Publik)" http://journal.unair.ac.id.

Diah Nur Fitriana. 2014. "Inovasi Pelayanan Publik BUMN (Studi Deskriptif tentang Inovasi Boarding Pass System dalam Meningkatkan Kualitas Pelayanan Kereta Api PT KAI di Stasiun Gubeng Surabaya)" Vol. 3 No. 1. http://journal.unair.ac.id.

Lusi Widhiyanti Yanuaria. 2012. "Strategi PT. Kereta Api Indonesia (KAI) Dalam Meningkatkan Pelayanan Transportasi Kereta Api (Studi Kasus di Kantor Daerah Operasi VII Madiun Periode 2009-2011)" http://eprints.uny.ac.id.

\section{Sumber Undang-Undang :}

UU RI No. 19 Tahun 2003 Pasal 2, Tentang Badan Usaha Milik Negara (BUMN).

UU RI No. 19 Tahun 2003 Pasal 4 ayat (3), Tentang Pemisahan Kekayaan Negara.

UU RI No. 23 Tahun 2007, Tentang Perkeretaapian.

UU RI No. 25 Tahun 2009 Pasal 1 Ayat (4), Tentang Pelayanan Publik.

\section{Sumber Internet :}

Anonymous. 2012. Tinjauan Pustaka. Diakases dari http://e-journal.uajy.ac.id pada tanggal 9 Oktober 2017, pada pukul 10.00 .

Anonymous. 2014. Tinjauan Pustaka. Diakses dari http://elib.unikom.ac.id pada tanggal 19 Oktober 2017, pukul 09.45.

Anonymous. 2015. Introduction. Diakses dari file://C:/Users/Acer/Downloads pada tanggal 30 November 2017, pukul 21.20.

Anonymous. 2015. Tinjauan Pustaka. Diakses dari http://e-journal.uajy.ac.id pada tanggal 9 Oktober 2017, pukul 09.50.

Anonymous. 2014. Tinjauan pustaka. Diakses dari http://digilib.unila.ac.id pada tanggal 1 Desember 2017, Pukul 21.03.

Anonymous. 2014. Metodologi Penelitian, Diakses dari http://a-research.upi.edu pada tanggal 1 Desember 2017, Pukul 21.11.

Anonymous. 2013. Kajian Pustaka, Kerangka Pemikiran dan Hipotesis, diakses dari http://repository.unpas.ac.id pada tanggal 1 Desember 2017, Pukul 20.41 